\title{
Budaya Organisasi dalam Pelayanan Keperawatan di Ruang Rawat Inap Rumah Sakit Ibu dan Anak Kumala Siwi Jepara
}

\author{
Arief Yustiawan* \\ * Fakultas Kedokteran dan Ilmu - Ilmu Kesehatan Universitas Jenderal Soedirman \\ Purwokerto \\ Email : arief024@gmail.com
}

\section{ABSTRACT:}

The role of nurses in the hospital is very substantial in the implementation of nursing services but there is the role of nurses appear obstacles in addition to synergize with the goals expected by the hospital, the nurse also has a contract with the social with patients and the profession organization. This study was a descriptive qualitative study. Data were collected by in depth interviews on 3 nurses as main informants and 2 as triangulation informants. Data were analyzed by content analysis method. Research shows the application of organizational culture in nursing service is not well understood. The socialization of hospital values in service delivery already infrormed through written media and direct examples. The values related to nursing services following the principles of speed, hard work, professional, obedient to the rules, effective and efficient. These values and culture conveyed directly from the founders and monitored its implementation by the head section.

Keywords: nursing service, hospital, organizational culture

\section{PENDAHULUAN}

Besar kecilnya keterlibatan karyawan dalam penerapan value dan asumsi-asumsi merupakan bagian dari kekuatan dari sebuah budaya organisasi sehingga budaya organisasi dapat dijadikan sebagai keunggulan bersaing yang lebih sulit ditiru oleh organisasi lain karena keberhasilan di dalam organisasi sangat dipengaruhi dari kinerja karyawan. Oleh karena itu sangat penting melakukan pembelajaran terus menerus agar dapat membentuk suatu budaya yang baik bagi organisasi. ${ }^{1}$

Aplikasi dari budaya organisasi dapat meningkatkan kemampuan seseorang untuk meningkatkan produktivitas kerjanya serta produktivitas karyawan akan berpengaruh positif terhadap kinerjanya di rumah sakit secara keseluruhan dan lebih jauh lagi dapat memberi dampak pada kelangsungan hidup rumah sakit di masa yang akan datang. Budaya organisasi yang terdiri dari artefak, nilai-nilai, dan asumsiasumsi dasar yang dapat diterapkan pada seluruh organisasi-organisasi seperti rumah sakit sehingga perlu membuat suatu misi dengan melihat kejelasan arah dan tujuan masa yang akan datang sehingga karyawan di rumah sakit akan lebih terarah berdasarkan kesesuaian job description. ${ }^{2}$

Penerapan konsistensi terhadap nilainilai yang dapat dimengerti dan dianut seluruh karyawan dalam keterlibatannya pembuatan misi serta partisipasi aktif seluruh karyawan dalam mendukung akan tercapainya sebuah misi akan terlihat kreativitas dalam hal pekerjaan. Hal tersebut akan memudahkan adaptabilitas 
terhadap lingkungan ekternal maupun internal dan pada akhirnya kualitas para karyawan akan meningkat dengan ditandainya penyelesaian tugas dengan baik dan benar, tidak ada kesalahan dalam hal pekerjaan, pelayanan menjadi baik, kedisiplinan, kerjasama antar karyawan baik, serta inovasi dan kreativitas meningkat. ${ }^{3}$ Peran perawat di rumah sakit sangat besar dalam pelaksanaan pelayanan keperawatan.

Selama ini peran perawat cenderung dalam hal melakukan pelayanan sematamata demi dirinya atau profesinya sendiri. Seorang perawat tetap harus berperilaku secara profesional dalam melaksanakan pelayanan keperawatan karena itu kewajiban dari kontrak sosialnya dengan pasien akan tetapi sering dilupakan bahwa perawat juga memiliki kontrak sosial dengan organisasi. Tidak mudah mensinergikan perawat untuk berkontribusi terhadap pencapaian yang diinginkan oleh rumah sakit sebagai sebuah organisasi bisnis. ${ }^{4}$

Proses koordinasi terhadap perencanaan dalam hal pengembangan ruangan rumah sakit antara bagian keperawatan dengan manajemen masih belum berjalan dengan baik. Selain itu terdapat anggapan bahwa struktur organisasi yang telah ditetapkan tidak dijalankan serta ditemukan bahwa hanya sedikit kepala ruang memberikan orientasi kepada staf baru. Masih belum konsisten agenda rapat rutin dalam hal monitoring dan evaluasi. Budaya merupakan pegangan kepada anggota organisasi untuk melihat, berpikir dan merasakan dalam menjalankan organisasi, oleh karena itu budaya perlu diwariskan agar tidak hilang dan pudar. Budaya organisasi diajarkan melalui proses sosialisasi dimana anggota baru dapat melihat dan menyesuaikan kebutuhan organisasi dengan asumsi dasar sebagai pedoman. ${ }^{5}$

Budaya yang diajarkan sebenarnya pada aspek permukaan yang tampak saja (artefak), hal ini asumsi dasar sebagai inti dari budaya tidak akan terungkap dalam aturan perilaku yang diajarkan karena asumsi dasar merupakan aspek yang tidak dapat dilihat dan tidak tampak di permukaan.

Sosialisasi dapat dikonsepkan sebagai proses yang terdiri atas tiga tahap yaitu kedatangan, keterlibatan (encounter) dan metamorfosis. Tahap pertama mengarah pada semua pembelajaran yang dilakukan sebelum karyawan baru bergabung dengan organisasi. Tahap kedua, karyawan baru berusaha mencari seperti apa organisasi tersebut dan membandingkan keadaan yang diharapkan dengan realita yang mungkin saja berbeda. Tahap ketiga, muncul dan berlaku perubahan yang relatif bertahan lama. Proses dengan ketiga tahap ini berpengaruh terhadap produktivitas kerja dan komitmen karyawan baru terhadap tujuan organisasi dan keputusan mereka untuk bergabung dengan organisasi.

Peningkatan pelayanan keperawatan dapat diupayakan dengan meningkatkan kinerja perawat yaitu dengan peningkatan pengetahuan melalui pendidikan keperawatan berkelanjutan dan peningkatan keterampilan keperawatan sangat mutlak diperlukan. Penataan lingkungan kerja yang kondusif perlu diciptakan agar perawat dapat bekerja secara efektif dan efisien.

\section{METODE PENELITIAN}

Rancangan penelitian ini menggunakan rancangan kualitatif yang disajikan secara deskriptif eksploratif melalui observasi dan wawancara mendalam. Penelitian dilaksanakan pada bulan Juli sampai dengan Desember tahun 2017 yang berlokasi di Rumah Sakit Ibu dan Anak Kumala Siwi Kabupaten Jepara. Pengumpulan data dilakukan sekaligus pada satu kali kegiatan pengamatan. Metode sampling yang digunakan adalah purposive sampling. Pengumpulan data dengan cara wawancara mendalam (indept interview), observasi dengan mengggunakan daftar checklist dan telaah dokumen. 


\section{HASIL DAN PEMBAHASAN}

Berdasarkan bahwa ketiga informan yaitu perawat pelaksana di ruang rawat inap. Informan pertama berusia 30 tahun, infroman kedua berusia 28 tahun, informan ketiga berusia 38 tahun. Ketiga informan memiliki jenis kelamin yang sama yaitu perempuan. Latar belakang pendidikan ketiga informan yaitu diploma tiga (D3) keperawatan. Ketiga informan memiliki masa kerja yang berbeda-beda informan pertama dengan masa kerja 8 tahun, infroman kedua masa kerja 5 tahun dan informan ketiga masa kerja 9 tahun.

Sedangkan informan triangulasi adalah kepala seksi keperawatan berusia 35 tahun dan kepala ruang rawat inap berusia 31 tahun, berjenis kelamin perempuan, latar belakang pendidikan untuk kepala seksi keperawatan yaitu sarjana keperawatan dengan profesi Ners dan kepala ruang pendidikan terakhir diploma tiga keperawatan. Pengalaman kerja di rumah sakit dimana kepala seksi keperawatan memiliki masa kerja 14 tahun, sedangkan kepala ruang memiliki masa kerja 9 tahun, sehingga dapat dikatakan informan triangulasi mempunyai pengalaman kerja yang lebih cukup lama dan kompeten di rumah sakit.

Upaya penerapan budaya organisasi di pelayanan keperawatan yang dilakukan oleh pihak manajemen yaitu pemahaman tentang perencanaan, kegiatan-kegiatan, dan implementasi budaya organisasi oleh manajemen rumah sakit. Perencanaan dan penerapan budaya organisasi dibentuk dengan pedoman atau panduan dalam sebuah buku panduan pelayanan keperawatan karena pedoman tersebut sebagai acauan dalam melaksanakan pekerjaan. Setiap perawat yang bergabung di rumah sakit akan diberikan pengetahuan seputar kegiatan di rumah sakit, penyampaian pengetahuan terhadap perawat baru dan lama tersebut dengan cara mengadakan sosialisasi atau pertemuan yang terencana. Setelah diberikan pemahaman melalui sosialisasi atau pertemuan kepada perawat lama maupun baru akan dilaksanakan monitoring dan evaluasi secara berkala.

Hasil dari evaluasi terhadap pelaksanaan budaya organisasi akan ditindak lanjuti oleh kepala seksi keperawatan untuk mendapatkan alternatif pemecahan masalah melalui pertemuan bersama dengan perawat pelaksana di ruang rawat inap, sehingga didapatkan solusi dari masalah pelaksanaan budaya organisasi diruang rawat inap. Solusi tersebut dari kepala seksi keperawatan akan diteruskan kepada pimpinan agar mendapatkan arahan dan keputusan.

Organisasi membangun serta mempertahankan budaya asli diperlihatkan dari filsafat pendirinya sehingga sangat mempengaruhi kriteria yang digunakan dalam memperkerjakan karyawannya. Tindakan yang berasal dari menajemen puncak akan menentukan iklim umum berupa perilaku baik yang dapat diterima maupun tidak. Karyawan yang telah mendapatkan sosialisasi tentang budaya, kesuksesan yang dicapai sangat tergantung pada kecocokan nilai-nilai yang telah dianut oleh karyawan baru dengan nilainilai organisasi dalam proses seleksi maupun pada preferensi. ${ }^{2}$

\section{Pelaksanaan visi, misi, dan tujuan}

Pemahaman visi, misi, dan tujuan sebagai artefak diperoleh melalui proses sosialisasi sebagai langkah perkenalan terhadap makna dan mengungkapkan nilainilai agar dapat berperilaku sesuai budaya yang diinginkan. ${ }^{1}$ Sosialisasi dilaksanakan dengan mengadakan kegiatan internal, workshop, dalam rapat, saat orientasi, kegiatan rutin seperti doa bersama dan senam pagi. Peranan tokoh dalam menyampaikan simbol-simbol seperti visi, misi, logo, motto, serta brand nama rumah sakit dilakukan oleh pemiliki dalam hal ini langsung ketua yayasan, direktur, pihak dari manajemen.

Nilai pada level organisasi terkadang dikaitkan dengan prinsip moral dan etika hal ini dikarenakan nilai dipahami oleh 
para anggota organisasi melalui norma yang pada gilirannya akan merujuk kepada perilaku tertentu yang dianggap sesuai bagi kelompok tersebut. ${ }^{6}$ Pengenalan terhadap nilai-nilai dilakukan supaya secara menyeluruh berperilaku sesuai dengan budaya yang ada. Beberapa tahap dijalankan mulai dari tahap pra kedatangan dilakukan saat masa orientasi, tahap perjumpaan dalam hal ini seluruh perawat melihat secara nyata yang terjadi di rumah sakit, dan terakhir tahap metamorfosis merupakan tahap dimana seluruh perawat melakukan penyesuaian terhadap nilai dan norma yang ada diruang rawat inap. Semua tahap dilakukan dengan cara melakukan kegiatan-kegiatan rutin seperti doa bersama, pergantian shift, senam pagi, dan seminar atau workshop di rumah sakit.

Kendala yang dihadapi saat menjalankan nilai-nilai dalam visi, misi, dan tujuan dalam keprawatan yaitu kegiatan pendidikan dan pelatihan tidak sesuai dengan program kerja, sarana prasarana tidak memadai, pemberian asuhan keperawatan tidak menggunkan standar prosedur operasional, dan bekerja menggunakan penafsiran sendiri yang dianggap memudahkan pekerjaan.

\section{Penerapan struktur organisasi yang ada diruang rawat inap}

Struktur organisasi terdiri dari struktur, bentuk, dan bagan untuk menggambarkan adanya pola hubungan antar bagian atau staf, antar atasan secara vertikal maupun horisontal, serta mengelompokkan tugas dan wewenang sesuai dengan sistem penugasan yang ada dirungan. Struktur organisasi juga digunakan untuk menetapkan bagaimana tugas diberikan, alur pelaporan, mekanisme koordinasi formal serta pola interaksi. Proses pengenalan struktur organisasi disampaikan oleh direktur, kepala seksi keperawatan, dan kepala instalasi melalui kegiatan orientasi, kegiatan rutin yang diadakan oleh rumah sakit, dan saat berada diruangan. ${ }^{7}$
Menurut informan utama menyatakan belum ada bentuk fisik struktur oraganisasi sehingga tidak adanya kejelasan terhadap informasi serta pelaksanaan pengaturan peran di dalam menjalankan pemberian tugas. Nilai-nilai yang diselenggarakan dalam sebuah organisasi perlu adanya role model atau teladan bagi yang lain agar mampu mengkomunikasikan keyakinan-keyakinan yang dijalankan di rumah sakit sehingga perlunya setiap peran struktur dalam memberikan makna dalam sebuah tindakan atau contoh nyata dalam melaksanakan kegiatan sehari-hari.

\section{Penyampaian informasi dan sumber daya manusia keperawatan}

Penyampaian terhapadap nilai-nilai dan keyakinan yang dimiliki dalam sebuah organisasi untuk menentukan kuat atau lemahnya anggota dalam menerapkan budaya. $^{7}$ Oleh karena itu perlu mengadakan pertemuan tahunan yang memiliki fungsi sebagai memperkuat bentuk perilaku dalam individu dengan cara memberikan hadiah-hadian atau semacanya yang dianggap berjasa dalam melaksanakan pekerjaannya. Menurut informan utama menyatakan belum pernah mendapatkan hasil terkait yang telah dikerjakan sehingga tidak memahami kekurangan apa yang perlu dilakukan perbaikan. Hasil kegiatan pelayanan dilakukan evaluasi setiap enam bulan sekali, hasil tersebut hanya menampilkan kegiatan pelayanan secara kesluruhan yang ada dirumah sakit.

Sumber daya manusia merupakan sumber yang memiliki akal, perasaan, keinginan, kemampuan, keterampilan, pengetahuan, dorongan, daya dan karya akan berpengaruh terhadap pemenuhan pencapaian tujuan yang diharapkan oleh organisasi. ${ }^{8}$ Berdasarkan informasi dari informan menyatakan bahwa jumlah tenaga di keperawatan belum memenuhi pola ketenagaan sehingga yang terjadi adalah peningkatan beban tugas pekerjaan. Nilai-nilai sebagai prinsip, tujuan, dan 
standar-standar sosial dalam kelompok keperawatan dalam melaksanakan pelayanan yang sangat diperhatikan atau diyakini yaitu kejujuran, kedisplinan, tanggungjawab, kerjasama, attitude, profesionalisme, dan loyalitas.

\section{Penugasan pemberi asuhan dan landasan model pendekatan kepada pasien}

Dalam penerapan sistem pemberian asuhan keperawatan atau penugasan harus merefleksikan falsafah organisasi, struktur, pola ketenagaan, dan karakteristik populasi pasien yang dilayani. ${ }^{9}$ Menurut informan pelaksanaan sistem asuhan keperawatan melalui standar prosedur operasional yang disampaikan oleh kepala ruang, kepala instalasi dan kepala seksi keperawatan.

Nilai-nilai yang dianut dan diyakini selama menjalankan penugasan dikaitkan dengan prinsip moral atau etika yang akan membentuk perilaku yang diharapkan setiap orang terhadap berbagai situasi, nilai yang diterapkan diruang rawat inap dalam melaksanakan tugas menggunakan atas dasar cepat selesai tanpa meihat melihat atau berpedoman kepada nilai-nilai yang telah ditetapkan. Hal ini dikarenakan beberapa permasalahan merasa adanya ketidakadilan dalam pembagian tugas dengan yang lain, penggunaan asumsiasumsi sendiri sehingga membentuk karakter sendiri diruang rawat inap.

\section{Kesadaran dan motivasi dari seluruh tanaga keperawatan yang ada.}

Dalam memberikan pelayanan keperawatan selalu berpedoman terhadap tujuan yang ingin dicapai rumah sakit dengan memegang prinsip kecepatan, kerja keras, profesional, patuh terhadap aturan, efektif dan efisien. Pelaksanakan pelayanan keperawatan seluruh perawat ruangan selalu diberikan pemahaman tentang tujuan yang ingin dicapai rumah sakit dan selalu berpegang terhadap nilainilai yang ada di rumah sakit. ${ }^{9}$ Seseorang memiliki kesadaran dan motivasi apabila terdorong berbuat atau melaksanakan suatu kegiatan langsung mengarahkan energi untuk mencapai tujuan, mempunyai intensitas perasaan-perasaan yang berbeda dalam pencapaian tujuan.

Tugas-tugas yang diberikan kepada perawat selalu disikapi dengan tetap menjalankan dengan maksimal dan profesional hal ini perawat yang ada di ruang rawat inap memahami nilai-nilai kedisiplinan, kejujuran, kerjasama, tanggungjawab, dan profesional sehingga tugas selalu diselesaikan kendala yang terjadi adalah tugas tambahan yang diberikan tidak selalu dapat dikerjakan dengan target waktu yang disepakati hal ini akan mengganggu kegiatan-kegiatan lainnya. Permasalahan yang terjadi akibat tidak adanya penghargaan yang diberikan kepada perawat atas pelaksanaan tugas.

Upaya yang dilakukan pimpinan untuk memberikan motivasi, kepercayaaan, antusias dan terbuka dengan melakukan pelatihan yang disupervisi oleh manajer keperawatan. Selain itu upaya lain yang dilakukan yaitu dengan mengadakan interaksi dengan cara menceritakan pengalaman berharga dan kisah-kisah selama bekerja, menceritakan arahanarahan bagaimana menanggapi komplain pasien, memberikan respon terhadap tuntutan-tuntutan dari luar rumah sakit, memberikan pengetahuan bagaimana rumah sakit dapat bertahan dalam meghadapi tuntutan-tuntutan dalam pelayanan. Sehingga perawat yang terlatih akan memberikan perubahan di ruang rawat inap sesuai dengan nilai-nilai yang berlaku.

\section{Komitmen dari pimpinan rumah sakit}

Menciptakan suasana kerja yang dapat mendorong perawat untuk melakukan yang terbaik, diperlukan seorang pemimpin. Pemimpin tersebut harus mempunyai kemampuan untuk memahami bahwa seseorang memiliki motivasi yang berbeda-beda. ${ }^{10}$

Keterikatan seseorang melakukan yang terbaik bersama dengan pimpinan salig bekerjasama dalam melaksanakan 
tugas pokok yang diberikan dengan mengerahkan, mempengaruhi, mendorong kearah tujuan yang ingin dicapai. ${ }^{11}$ Komitmen bersama terlihat keinginan untuk membangun kerja tim dalam pelayanan keperawatan karena dilandasi dengan nilai bahwa bekerja adalah ibadah dan bekerja dengan ikhlas. Selain itu segala peraturan dan etika berusaha agar selalu mentaati, hal ini terlihat adanya tindakan saling hormat menghormati antar perawat pelaksana sampai dengan atasan, kepada orang yang lebih tua, kelurga pasien dan pasien itu sendiri.

Permasalahan yang terjadi dalam pelayanan keperawatan di ruang rawat inap dikarenakan perawat tidak dapat bekerjasama, kurang efisien dalam memberikan pelayanan, kurang produktif dalam bekerja, oleh karena itu perlu adanya penyelesaian yang dilakukan dengan mengadakan rapat atau pertemuan rutin maupun insidentil atau rapat dengan kepala seksi keperawatan agar dapat dibuat suatu peraturan atau kebijakan. Hal ini membutuhkan komitmen pimpinan untuk dapat menyelesaikan masalah yang terjadi dengan lebih efektif dan efisien.

\section{KESIMPULAN}

Pelaksanaan budaya organisasi meliputi artefak, nilai-nilai, dan asumsiasumsi dasar terhadap faktor-faktor yang mempengaruhi pelayanan keperawatan, didapatkan bahwa penanaman visi, misi dan tujuan rumah sakit telah dilaksanakan sesuai dengan budaya organisasi yang ada diterapkan oleh rumah sakit. Penerapan struktur organisasi di ruang rawat inap belum terpenuhi sehingga pelaksanaan tugas kurang maksimal.

Sumber daya keperawatan dengan jumlah yang kurang memadai sehingga pelaksanaan budaya organisasi di ruang rawat inap tidak berjalan dengan baik. Pelaksanaan metode penugasan kepada pasien tidak mengacu kepada falsafah yang dibangun rumah sakit, pola ketenagan, serta karakteristik populasi pasien dalam memberikan asuhan keperawatan. Kesadaran dan motivasi terhadap pekerjaan dilaksanakan secara profesional dan maksimal sesuai dengan penerapan nilai-nilai rumah sakit. Komitmen dari pimpinan terjalin dengan baik antar perawat pelaksana atau dibagian lain.

\section{DAFTAR PUSTAKA}

1. Sutrisno E. Budaya Organisasi. Jakarta: Kencana Prenada Media Group, 2010.

2. Ekwutosi OC, Moses OS. Internalization of Organizational Culture: A Theoretical Perspective. Int J Bus Tour Appl Sci 2013; 1: 7796.

3. Hasibuan MSP. Manajemen Sumber Daya Manusia. Ed Revisi Jakarta Bumi Aksara. Epub ahead of print 2011 DOI: 10.1017/CBO9781107415324.004.

4. Dikmen Y, Karataș H, Gürol Arslan $\mathrm{G}$, et al. The Level of Professionalism of Nurses Working in a Hospital in Turkey. J Caring Sci 2016; 5: 95-102.

5. Fleury MTL. Organizational culture and the renewal of competences. $B A R$ - Brazilian Adm Rev 2009; 6: 1-14.

6. Jackson TA, Meyer JP, Wang X-H (Frank). Leadership, Commitment, and Culture: A Meta-Analysis. $J$ Leadersh Organ Stud 2013; 20: 84106.

7. Zheng W, Yang B, McLean GN. Linking organizational culture, structure, strategy, and organizational effectiveness: Mediating role of knowledge management. J Bus Res 2010; 63: 763-771.

8. Mathis RL, Jackson JH. Human Resource Management. 13th Editi. Mason: South-Western Cengage Learning, 2010.

9. Nursalam. MANAJEMEN KEPERAWATAN: Aplikasi dalam Praktik Keperawatan Profesional Edisi 3. 2011. Epub ahead of print 2011. DOI: 10.1001/archinte.165.22.2659. 
10. Naderi N, Jadidi L. The Study of the effects between Leadership Style, Organization Culture, Employees Performance on Leadership Performance (Case: Government Hospitals in Isfahan). Int $J$ Acad Res Bus Soc Sci 2014; 12: 187-198.

11. Zehir C, Ertosun ÖG, Zehir S, et al. The Effects of Leadership Styles and Organizational Culture over Firm Performance: Multi-National Companies in İstanbul. Procedia - Soc Behav Sci 2011; 24: 1460-1474. 